\title{
Experiences of Judeo-Christian Students in Undergraduate Biology
}

\author{
M. Elizabeth Barnes, Jasmine M. Truong, and Sara E. Brownell* \\ Biology Education Research Lab, School of Life Sciences, Arizona State University, \\ Tempe, AZ 85287-4501
}

\begin{abstract}
A major research thrust in science, technology, engineering, and mathematics (STEM) education is focused on how to retain students as STEM majors. The accumulation of seemingly insignificant negative experiences in STEM classes can, over time, lead STEM students to have a low sense of belonging in their disciplines, and this can lead to lower retention. In this paper, we explore how Judeo-Christian students in biology have experiences related to their religious identities that could impact their retention in biology. In 28 interviews with Judeo-Christian students taking undergraduate biology classes, students reported a religious identity that can conflict with the secular culture and content of biology. Some students felt that, because they are religious, they fall within a minority in their classes and would not be seen as credible within the biology community. Students reported adverse experiences when instructors had negative dispositions toward religion and when instructors were rigid in their instructional practices when teaching evolution. These data suggest that this may be a population susceptible to experiences of cultural conflict between their religious identities and their STEM identities, which could have implications for retention. We argue that more research should explore how Judeo-Christian students' experiences in biology classes influence their sense of belonging and retention.
\end{abstract}

\section{INTRODUCTION}

To meet the societal needs of the 21st century, colleges and universities must increase the number of students graduating with science, technology, engineering, and math (STEM) degrees (President's Council of Advisors on Science and Technology, 2010; American Association for the Advancement of Science [AAAS], 2011). In an attempt to increase the number of STEM students, there have been national calls for researchers to explore factors that influence students' persistence in STEM majors. One prominent factor that has been shown to influence students' persistence in a STEM major is their sense of belonging (Espinosa, 2011; Strayhorn, 2011, 2012; Good et al., 2012; Brown et al., 2016). Sense of belonging has been characterized as whether a student feels as though he or she "fits in" or "belongs" in his or her academic community (Trujillo and Tanner, 2014) and is related to a student's social and academic integration into a discipline (Tinto, 1993; Freeman et al., 2007; Good et al., 2012; Strayhorn, 2012). When a student feels a strong sense of belonging in a domain, he or she is more likely to feel as though he or she is a part of the discipline rather than on the fringe of the discipline (Good et al., 2012).

The concept of sense of belonging stems from work focused on understanding why students, particularly those from historically marginalized groups, decide to leave college or switch majors (Tinto, 1993; Trujillo and Tanner, 2014). More recently, researchers who were exploring students' sense of belonging in undergraduate STEM programs have found that a student's sense of belonging predicts both intent to persist (Good et al., 2012) and actual persistence as a STEM major (Espinosa, 2011).

A major factor that can affect students' sense of belonging is whether they feel they are part of a group that is negatively stereotyped. When students think their peers
Katayoun Chamany, Monitoring Editor Submitted April 15, 2016; Revised October 11, 2016; Accepted November 14, 2016 CBE Life Sci Educ March 1, 2017 16:ar15 DOI:10.1187/cbe.16-04-0153

*Address correspondence to: Sara E. Brownell (Sara.brownell@asu.edu).

(c) 2017 M. E. Barnes et al. CBE-Life Sciences Education (๑) 2017 The American Society for Cell Biology. This article is distributed by The American Society for Cell Biology under license from the author(s). It is available to the public under an Attribution-Noncommercial-Share Alike 3.0 Unported Creative Commons License (http:// creativecommons.org/licenses/by-nc-sa/3.0). "ASCB®" and "The American Society for Cell Biology ${ }^{\circledR}$ " are registered trademarks of The American Society for Cell Biology. 
and/or instructors hold a negative stereotype about their groups (i.e., gender group, ethnic group, etc.), this can result in the students feeling a low sense of belonging within their disciplines (Good et al., 2012; Brown et al., 2016). For instance, Brown et al. (2016) found that African-American students in STEM who reported experiences of subtle or overt forms of racism in their disciplines were more likely to report a low sense of belonging in those disciplines. Similarly, another study found that, when women in mathematics perceive that there is a negative stereotype about their gender's ability, they tend to have a lower sense of belonging in math (Good et al., 2012). Good and colleagues speculated that persistence in STEM will be affected by a low sense of belonging by individuals within any group who are repeatedly met with experiences that imply their groups are stereotyped negatively within their disciplines.

We suspect that Judeo-Christian students in biology may feel that religious individuals are negatively stereotyped in biology due to several factors that are characteristic of the culture of the biological sciences. First, there is a cultural perception in the United States that biology and religion are in conflict (Scott, 2005; Numbers, 2006). Core areas of biology, such as evolution (AAAS, 2011; Brownell et al., 2014), are often presented as incompatible with religious beliefs by many individuals in the public, including scientists (Harris, 2005; Dawkins, 2009; Coyne, 2015), religious leaders (Ham, 2010), and politicians (Satlin, 2012). Additionally, past research shows that students' discourse with their friends and family outside class on topics such as evolution can lead students to perceive a conflict between religion and evolution (Winslow et al., 2011). It could be that Judeo-Christian students come into the classroom with the preconception that there is a tension between their religious identities and biology, which could make them feel negatively stereotyped in biology classes.

Second, previous research has shown that the biology classroom is not always a comfortable environment for religious students. In past research, religious students said they felt alienated when instructors taught evolution and did not address the potential controversy with religion (Hermann, 2012). Additionally, research shows that instructors are often unwilling to acknowledge religious student perspectives when teaching evolution and unwilling to present evolution and religion as potentially compatible (Barnes and Brownell, 2016). Thus, it may be common for Judeo-Christian students to feel as though their perspectives are not acknowledged or respected when instructors teach relevant content.

Third, research has shown that Christian students can experience negative stereotypes in science generally (Rios et al., 2015), which implies that Christian biology students may also feel negatively stereotyped (Good et al., 2012). Rios et al., 2015 showed that Christian individuals perceive that there are negative stereotypes about their ability in science. Additionally, among a population of undergraduate Christian non-biology major students, the researchers showed that students who are aware of the negative stereotype about Christians in science underperform on tasks they are told are indicative of science ability (Rios et al., 2015), a phenomenon called stereotype threat (Steele and Aronson, 1995). Further, these Christian students who experienced stereotype threat subsequently said they identify less with science than did their counterparts who did not face stereotype threat (Rios et al., 2015). However, the researchers did not explore the authentic experiences of Christian students actually taking biology classes. We suspect that Judeo-Christian students in biology classes may also perceive that there are negative stereotypes about Judeo-Christians in biology, which subsequently could compromise their sense of belonging in biology and retention as biology majors (Good et al., 2012; Rios et al., 2015).

Fourth and finally, there is a disconnect between the percentage of religious ${ }^{1}$ individuals in the United States and the percentage of religious individuals who are biologists in the United States; while $83 \%$ of the public believe in God and 75\% identify with a Christian religious denomination (Pew Research Center, 2009), only $32 \%$ of biologists believe in God and 25\% identify with a Christian religious denomination (Ecklund and Scheitle, 2007; Pew Research Center, 2009). Even though Judeo-Christian students make up approximately half of introductory biology classes (Cooper, personal communication), they may perceive that few biologists are religious, and this perception may be further exaggerated by outspoken prominent atheist biologists (Harris, 2005; Dawkins, 2009; Coyne, 2015). Thus, similar to how many African-American students in STEM report negative experiences, in part because so few of their instructors are African American (Brown et al., 2016), Judeo-Christian students may report negative experiences in biology because so few of their biology instructors appear to be religious. While we draw a parallel here, it is important to consider that religious identity is often a covert identity and less visible than an identity such as race, which could make the identification of role models even more difficult for religious students.

In this study, we explored experiences of Judeo-Christian students in biology classes that could lead them to feel uncomfortable in biology classes, and this is the first study to take this approach. Further, in an effort to understand how we may help Judeo-Christian students feel more comfortable in biology classes, we explored the positive experiences that Judeo-Christian students have in biology classes. This exploratory interview study represents a first step toward better understanding the experiences of religious students in college biology, and we hope that it will lay the foundation for future research on Judeo-Christian students' sense of belonging and retention as biology majors.

We set out to answer the following research questions:

1. What aspects of biology instruction are relevant to students' religious identities?

2. What interactions with peers/instructors make religious students feel comfortable or uncomfortable in biology classes?

3. What experiences do religious students have with biology peers and instructors that make them feel like they fit in and are valued, or not?

${ }^{1}$ In this study, we focus on students of a Judeo-Christian religious background. While the majority of religious students in our classes are Judeo-Christian, we recognize that not all religious students are from a Judeo-Christian background. When discussing past literature, we are as specific about the religious denominations of students as possible. When studies provide information about specific denominational characteristics, we report that denomination. However, when the study does not report the specific denominations of their students, we refer to these individuals as "religious." 


\section{METHODS}

\section{Recruitment}

We recruited a sample of religious students taking high-enrollment biology classes at a large, public, research-intensive university in the southwest United States. Recruitment took place during the Spring, Summer, and Fall semesters of 2015. Students were recruited using fliers that the research team distributed to students in majors and nonmajors introductory biology courses and upper-level biology courses, including genetics and evolution. The flier indicated that researchers were interested in talking to religious students about their experiences in biology classes and were offering compensation for a 30- to 45-minute interview. Students then used a link on the flier to sign up for an interview time via a Doodle poll using their names and email addresses.

\section{Data Collection}

When students arrived at the interview location, they were given an overview of the purposes of the study. They were told that the research team was interested in exploring experiences that may contribute to religious students' decisions to either stay or leave the biology major. We then conducted semistructured interviews. We asked students general questions about their negative and positive experiences in undergraduate biology classes that were relevant to their religious identities and generally how they felt as religious students in biology classes. As with many qualitative interview studies, our interview questions changed slightly throughout the data-collection period (Glaser and Strauss, 1967). However, a list of the general interview questions that were used can be found in Table 1. At the end of the interview, each participant was given a short questionnaire to determine gender, background in biology, religious saliency and religious activity, and personal perception of God's role in evolution and perception of the scientific view of God's role in evolution. The survey can be found in the Supplemental Material. Participants were compensated for their time with $\$ 15$ in cash at the end of the interviews.

All research was approved by the Arizona State University's IRB (protocol 00002555).

\section{Analysis}

The research team (M.E.B., J.M.T., and S.E.B.) transcribed half of the interviews and conducted preliminary analyses on these interviews. We used content analysis to identify predetermined themes that we had identified as being of interest before the data-collection phase (Krippendorff, 2012). We also used grounded theory to identify additional themes that emerged from the interview transcripts after data collection (Glaser and Strauss, 1967). After we felt that we had established a set of preliminary themes from the interviews, the remaining interviews were transcribed and analyzed to confirm that we had identified all preliminary themes. Then, we established more specific categories within each theme. For instance, within the theme "students see advantages to being religious in biology," there were two main subcategories created: "students think they can help other religious individuals understand biology" and "students think they bring a unique perspective to biology." Constant

\section{TABLE 1. Questions used throughout interviews}

Identity questions

Experiences with instructors

Experiences with peers

Sense of belonging

Perceptions of shared values with the biology community

Advantages/disadvantages to being religious in biology

Personal beliefs about religion and biology

Concluding remarks
What religious faith do you most closely identify with, if any? How did you come to that faith?

What is your major and why did you choose that major? What do you want to do when you finish school?

Can you describe a time when an instructor in your biology class talked about religion in a positive way? In a negative way? How did those experiences make you feel as a person of faith?

As a person of faith, can you describe an experience where your instructors in biology classes made you feel like they valued religion/religious beliefs? Did not value religion/religious beliefs? How did those experiences make you feel as a person of faith?

Have any of your instructors ever talked about how religion and science are different from one another? How did those experiences make you feel as a person of faith?

Have your peers in biology classes ever done anything that made you feel like they valued religion/religious beliefs? Did not value religion/religious beliefs? How did those experiences make you feel as a person of faith?

As a person of faith do you feel like you "fit in" in biology classes? Why or why not?

As a person of faith, do you feel like you "fit in" with the broader community of biologists? Why or why not?

As a person of faith, do you feel like you can make friends with other students in your biology classes? Why or why not?

Do you think a person can be religious and a biologist? What percent of biologists do you think are religious?

If an instructor is religious would it matter for you to know that they were religious? Why or why not?

If an instructor were religious would it make you more likely to talk to them outside of class or raise your hand in class? Why or why not?

Can you describe any reason that being religious would be an advantage to you as a biologist? A disadvantage?

Can you describe any way in which you think your religious beliefs conflict with the science of biology?

Describe how you view the relationship between religion and biology. Have any of these views been influenced by your biology instructors?

Do you have anything else you would like to add about your experiences as a person of faith and a person in a biology class? 
comparison methods (Glesne and Peshkin, 1992) were used throughout the analysis. That is, quotes that were assigned to specific themes and categories were gathered together and compared with one another throughout the analysis. This constant comparison of quotes was meant to ensure that the description of the theme and category adequately represented all quotes within the same group and that the quotes were not different enough from one another to necessitate a separate category or theme. NVivo qualitative analysis software was used to organize the final coding of all interviews, but we did not use the automatic coding feature. All codes were applied by a researcher manually.

\section{RESULTS}

\section{Interrater Reliability}

During and after the analysis of the data, we created a coding rubric. The coding rubric consisted of detailed descriptions of each theme and category that were established during the interview analysis. The rubric also included instructions on how to code the interviews, which was reflective of our process during the final round of coding. To establish that the coding scheme was reliable and could be used to replicate the results by other researchers, the second author (J.M.T.) independently coded $10 \%$ of the statements coded by the first author (M.E.B.) in her final round of coding, and the two results were compared. The coding done by the two researchers agreed $87 \%$ of the time. However, reporting percent agreement for interrater reliability may inflate agreement rates, because percent agreement does not take into account agreement that would occur by chance alone (Hallgren, 2012). Therefore, in addition to percent agreement, we also used a Kappa statistic to measure the observed level of agreement among raters and control for agreement that would happen by chance. Cohen's kappa was calculated in SPSS 21 for each coded statement and then averaged. Cohen's kappa was greater than 0.70 for all codes reported in this paper, and the average Cohen's kappa for all codes reported in the paper was 0.81 , which indicates very high agreement (Landis and Koch, 1977). Codes from the more expert author's analysis (M.E.B.) were assigned to excerpts in which there was disagreement about the coding of an excerpt.

\section{Demographics}

Our interview population consisted of 13 males and 15 females. There were six first years, 10 sophomores, 10 juniors, and two seniors. Almost all of the students were biology majors (25/28), but a few were nonmajors taking biology as an elective course $(3 / 28)$. Many of the participants indicated that they planned to earn higher than a bachelor's degree in a biology-related field (20/28), and 14 of these students said they planned to pursue a health/medicine-related degree. Only $4 / 28$ of our participants planned to earn a bachelor's degree as their highest degree in biology, and $3 / 28$ participants planned to obtain degrees in an unrelated field, as these were the non-biology major students. One student was unsure of the highest degree she expected to obtain.

\section{Religiosity}

As intended, all participants indicated in the survey that their religious beliefs were important to them, and all participants indicated they participated in religious activities. Participants reported relatively high rates of religious saliency and/or religious activity (Table 2). In the interviews, all participants said they identified with a Judeo-Christian religious faith. However, it is worth noting that we did not specify in our recruitment that we wanted to interview students from a Judeo-Christian religious background. Our flier stated that we were interested in the experiences of religious students in biology classes. However, only students from Judeo-Christian backgrounds responded to the flier. The large majority of participants $(25 / 28)$ identified with a denomination of Christianity (10 nondenominational, 7 Catholic, 2 Presbyterian, 1 Anglican, 1 Baptist, 1 LDS, 1 Lutheran, 1 Orthodox, 1 Protestant), and three participants identified with Judaism. Demographic data for each participant are outlined in Table 2 so that readers can contextualize student quotes.

\section{Research Findings}

While the majority of the students said that they felt accepted and respected in biology classrooms, the interviews also elicited responses from students that indicated that they may experience unique struggles in the context of undergraduate biology classrooms. Most participants said in their interviews that their overall experience in the biology community has been positive, but many students recalled negative experiences and/or negative perceptions in the biology community that related to their religious identities. While these instances were often subtle and infrequent, and it is difficult to ascertain the specific impacts of these experiences, the research literature on microaggressions and stereotype threat suggests that small, seemingly insignificant events can have a substantial impact on an individual's larger sense of belonging and identity (Steele et al., 2002; Murphy et al., 2007; Sue et al., 2007, 2009). Below, we outline both the positive and negative experiences that religious students reported having in biology. We have organized these findings into three main categories: 1) experiences students have navigating a religious identity in biology classes, 2) students' perceptions of the advantages and disadvantages to being religious in biology, and 3) students' perceptions of biology instruction as it relates to their religious identities.

Navigating a Religious Identity in Biology. The majority of students, but not all, reported that their religious identities can conflict with biology. However, many students also described unique ways in which they reconcile their religious identities with their biology identities. Students discussed how they have a general cultural perception that religion and biology conflict, and this presents a challenge to them before even coming to college. Further, many students cited evolution as a potential source of conflict with their religious identities, and our survey results show that students' beliefs about evolution are often different from what they perceive is the most accurate view according to current science. Mainly, while students believed in an influence of God on evolution, they also believed that their views are not compatible with the scientific view of evolution. However, despite potential conflicts, students demonstrated instances of reconciling their religious identities and biology identities using several strategies. These findings are further illustrated by the following student quotes.

Religious Students Reported That They Came into College with the Perception That Religion and Biology Are in Conflict. Throughout our interviews, many of the participants reported that their 


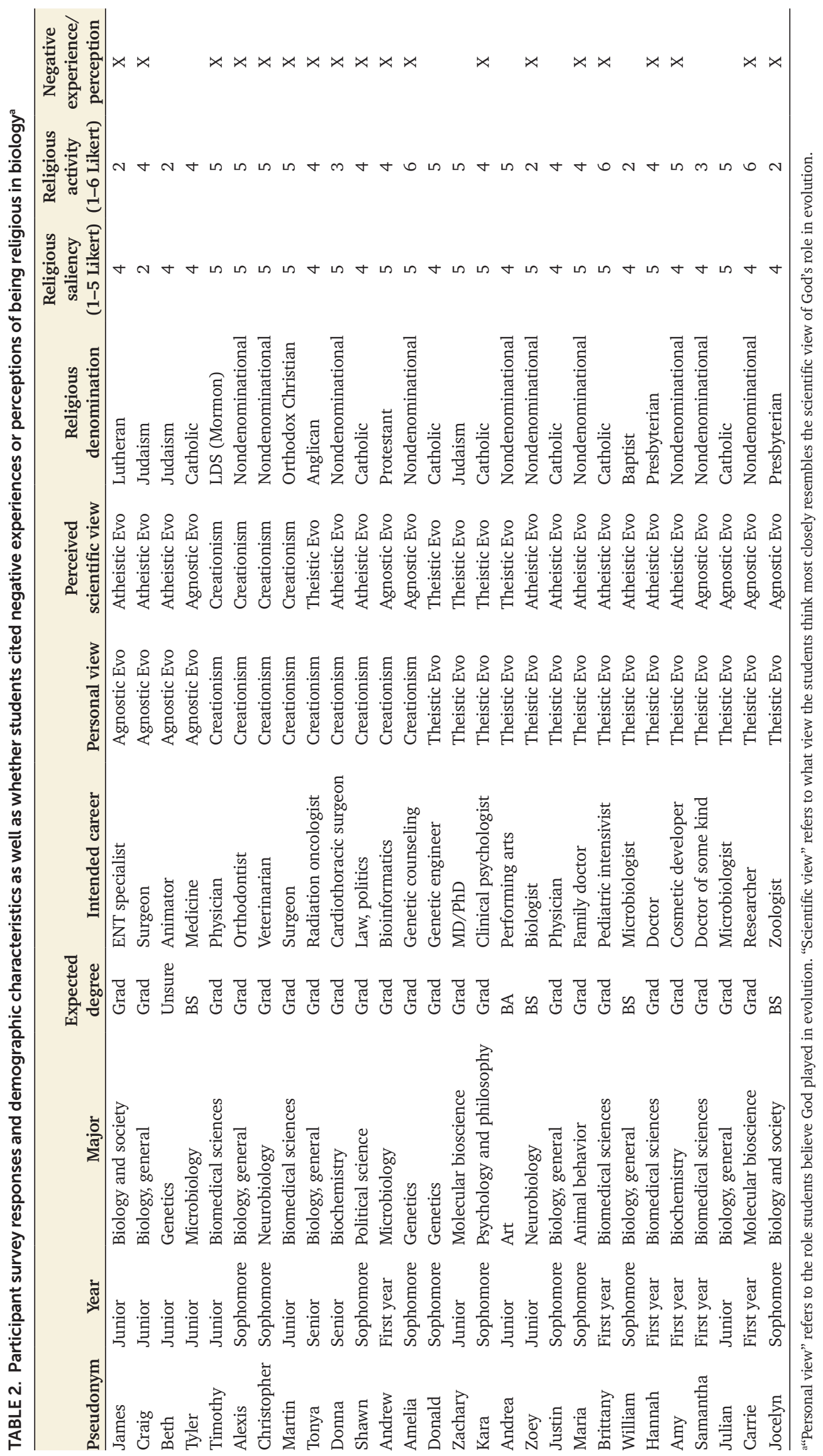


general experiences are that most people believe that biology and religion are in conflict.

"A lot of people think science and religion are completely separate from each other and it's like one or the other."-Christopher, nondenominational Christian

Some religious students said they already had this perception before enrolling in college biology classes. They expected that they would struggle in college as students of faith and biology majors because of the perceived conflict between religion and biology:

"I feel like anyone from a religious background who goes to a public college, they expect their professors when they are going to biology... there's going to be some sort of conflict in there ... I knew it would happen."-Alexis, nondenominational Christian

Further, the students expressed a general feeling that the biology community is not sympathetic to religion:

"Even in high school, it was a total battle fighting if [biology] is really right for me because I love science, but it's just the whole community is super insensitive about religion." -Brittany, Catholic

These findings indicate that Judeo-Christian biology students can have a perception that their religious identities may conflict with their aspirations in biology before they even enter a college biology course. This potentially pervasive conception illustrates how the perception of religion and biology as in conflict can come from outside sources separate from students' experiences in biology classes.

Students' Personal Beliefs about God's Role in Evolution Can Be in Conflict with Their Perceived Beliefs about How Scientists View the Involvement of God in Evolution. Eighteen participants indicated on our survey that they personally believe God either started or guided human evolution, a view often referred to as "theistic evolution" (Miller et al., 2006). Nine participants indicated that they believe humans were created in their present form by God, a view that is often labeled as "special creationism" (Scott, 2005). Four participants indicated they did not know whether God was involved in human evolution, but believed evolution occurred, a view that can be labeled "agnostic evolution" (Yasri and Mancy, 2016), and no participants said they believed God could not be involved in evolution, a view that is called "atheistic evolution" (Yasri and Mancy, 2016).

When asked what they thought was the most accurate scientific view of God's role in human evolution, 14 participants indicated that they thought the most accurate view, according to science, is atheistic evolution. Eight participants indicated they thought the most accurate scientific view is agnosticism of God's role in evolution. Four participants said that special creation is the most accurate scientific view, and four participants said that theistic evolution is the most accurate scientific view.

Notably, most students held beliefs about evolution that could be compatible with the scientific view of evolution (theistic evolution or agnostic evolution), but some of these students indicated that the most accurate scientific view of evolution was atheistic evolution, which would be incompatible with theistic evolution. Ten of our participants who said they personally believed in theistic evolution also believed that the most accurate scientific view was atheistic evolution. These responses are summarized in Table 2.

Religious Students Use Several Strategies to Reconcile Their Religious Identities with Biology. Although some students felt as though their peers and instructors see a conflict between biology and religion, students showed evidence of managing their religious identities with their aspirations to pursue a career in the field of biology. Students reported using several strategies to reconcile their religious identities with biology. The majority of students reported adapting their religious beliefs to accommodate biology knowledge. For instance, William talks about how he used to believe in special creationism, but after learning about evolution, he changed his beliefs:

"I was taught creationism and that's it. I didn't question it, that's just how things were. The flood came and two animals reproduced with each other and that's how we have all the animals today. That's basically what I used to believe. Now that I've been learning evolution ... and things of that nature, it's definitely made me look back and reassess certain perspectives that I have."-William, Baptist

Another strategy many students used to reconcile their religious identities with biology was to seek out and use role models who are religious scientists. Religious scientist role models have been shown in previous research to positively influence students' views on the relationship between religion and evolution (Winslow et al., 2011; Barnes et al., 2017):

\begin{abstract}
"I found a bunch of people I can look up to that have talked about both [religion and science]. There is a professor here ... he teaches physics and he's a member of my church, the Catholic Church, so he's a great person to go talk to like 'Hey, I'm struggling with these two things that seem contradictory. Can you help me find a way to put them together?' and he's been amazing."-Brittany, Catholic
\end{abstract}

Some students chose to restrict their biology identities to areas outside evolution in which they perceived no conflict with their religious beliefs. Even though evolution has been outlined as a core concept of biology (AAAS, 2011; Brownell et al., 2014), these students tried to segment biology into areas of less perceived conflict. For instance, Alexis reported that she would not see her religious beliefs as a barrier to her specific field of interest, but that she could have a problem if she were pursuing areas of biology that involve evolution:

"I don't think that it's going to be a big problem in the medical field but I think any time you work with animals or plants in a way that brings up evolutionary history or that normally brings up evolutionary history, I think that that really draws more attention when you don't agree with everyone else." -Alexis, nondenominational Christian

Students also restricted their interest in biology to specific courses that did not conflict with their beliefs. When students 
who subscribed to special creationism had to take courses that included content like evolution that they saw as conflicting, they said they would take the class just to get a good grade and get their degree, but they did not believe the material in the same way that they believe the material presented in other classes. For instance, Martin, a special creationist, said he learned the "correct" information about evolution so he can get a good grade, but he was not generally interested in it:

"I agree with the professor [about evolution] for the sake of the grade, for the sake of my GPA. But other than that, I don't even want to be interested in taking it."-Martin, orthodox Christian

And Tonya, also a special creationist, says she just learned the material for the test but chose not to believe it:

\begin{abstract}
"In general certain things they teach us about evolution, I just feel a certain kind of way, I just don't feel like it's right or it's true. I mean, I just learn it and memorize it for exam purposes but I don't necessarily believe it."-Tonya, Anglican
\end{abstract}

Students also expressed that they compartmentalize their religious identities in order to accommodate biology. They restricted their religious identities to their lives outside their biology classes and that is how they navigated being religious students in biology. Craig exemplifies this:

"I don't think of myself as a person of faith when I'm in a biology class, when I'm in recitation with my groups or I'm doing a group project with other students. So I have my friends in my classes and I don't really consider myself a person of faith. I consider myself more a biology student. So, I feel like I fit in because I kind of compartmentalize it. I can be a biology student now and on Friday night I can go to Shabbat or something."-Craig, Jewish

Finally, religious students who were able to reconcile their religious beliefs with biology saw themselves as different from other religious students who see a conflict. They said they were able to fit in within the biology community because they were more open-minded and less conservative about their beliefs than other religious individuals. For instance, several students, including Beth, said that they were different because they choose not to interpret religious documents literally:

"I can reconcile my own beliefs with what I've already learned because I believe that religious documents aren't meant to be taken as orthodoxly as some people do, where if it says seven days it was exactly seven days, no more, no less. I feel like it's just interpretation."-Beth, Jewish

These quotes illustrate that, although students see a conflict between their religious identities and their pursuits in biology, they are actively trying to reconcile the two using a diverse number of strategies.

The Perceptions of Religious Students about the Advantages and Disadvantages of Being Religious in Biology. Participants reported both advantages and disadvantages to being religious in biology. Some students said they thought it was advantageous to be religious in biology, because they could bring a diverse viewpoint to research and help other religious people appreciate or understand biology. However, students also said that there were some disadvantages to being religious in biology including that they see the potential for a low sense of belonging in biology and that their biology colleagues may undervalue their contributions. These findings are explored in detail in the following sections.

Religious Students See Their Unique Experiences as an Advantage in Biology. Students reported that they saw their religious identities as potentially valuable to the scientific community and other religious individuals. Many students thought that being religious in biology is valuable, because it brings a diversity to science that can help create new ideas, which aligns with current literature that outlines the benefits of diversity in science (Intemann, 2009). For instance, Christopher talked about how thinking differently can lead to a broader outlook on solving problems in biology:

"I mean I feel like I have a broader idea ... somebody that is not my faith is learning the same thing that I am. I just have a different outlook on a lot of things [in biology]."-Christopher, nondenominational Christian

Other students saw their religiosity as an opportunity to help other religious people become more comfortable with science. Students often said they thought they could communicate more effectively with the religious community about science than nonreligious biologists; since they are religious, they understand the perspectives of religious individuals better. For instance, Beth discussed the possibility that she could help educate religious individuals about biology:

"A large percentage of the United States is religious and I could help in making my research more accessible [...] it would definitely help with understanding where people are coming from because I feel like that's important regardless of what you're in but especially for biology since there are some people who might just flinch at evolution. I grew up where there were a lot of people who were offended by the idea of evolution."-Beth, Jewish

Further, Donna discussed how she is already trying to educate the younger religious children in her family about science:

"I think it's important for religious people to take up the field of biology to educate fellow religious people. So many people I try to educate ... like my brother and sister, who are younger than me; my sister wants to be a wildlife scientist. I know that she's going to be probably an animal physiology major. I've always reinforced ideas, like what I learn in science. Obviously my little brother and sister are super Christian because that's what they've grown up with, but I always tell them things that are inconsistent with the church. Now they're more open minded."-Donna, nondenominational Christian

Religious Students See Disadvantages to Being Religious in Biology. Although the religious students we interviewed often saw advantages to being religious, they more frequently cited 
disadvantages to being religious in biology. The majority of students said that they perceived a potential disadvantage to being religious in biology, and many of the students cited multiple disadvantages. Approximately half of the students we interviewed reported that they felt as though they are the minority in their classes. Some students, like Amelia, described feeling like it was hard to find others like themselves:

"I've only met a handful of people that are bio majors who go to my church. And that's really weird especially, like, girls, it's really hard to find females who are a biology major and religious. That's really, really difficult."-Amelia, nondenominational Christian

Further, Brittany went so far as to say that she wanted to feel a sense of community but did not feel that way, because she had a hard time connecting with others like herself in biology:

"I've always wanted a class about religion and biology, I would take that in a heartbeat, just for a sense of community because you feel like you're the only one."-Brittany, Catholic

Some students reported that they had experienced discomfort due to their peers in biology classes who would mock religion and religious people. For instance, Carrie reported that she was uncomfortable when she overheard her peers making fun of religious people who do not accept evolution:

\begin{abstract}
"There were a couple kids sitting behind me during the evolution lecture that were kind of just spouting like, 'people who don't believe in evolution are so stupid' and I personally believe in it [evolution] but I see how a lot of religious people could be offended by that and they were like 'Oh what, God made us?' they were like 'no it has to be some sort of process.' I was like, 'What you're saying right now could offend a lot of people' but I feel like they thought they were in a safe place because they were in the biology community. They were like 'oh we can just say this because everyone in here believes in evolution,' which may be the case but it was still kind of inappropriate in my opinion."-Carrie, nondenominational Christian
\end{abstract}

Sometimes students felt like they were in the minority when peers laughed at jokes that instructors made at the expense of religious individuals or agreed with instructor comments that were antireligious. For instance, Craig told a story about an instructor who was disproving the story of Noah's Ark with a negative disposition. All of his peers laughed at the professor's presentation and made Craig feel as though he was the only religious person in the class who disagreed with the professor:

"The [students'] laughter at the presentation during the Noah's Ark disapproval kind of thing. I think that kind of shows that everyone was with the professor on it."-Craig, Jewish

Students also reported that peers in class often assume that biology and religion have to be mutually exclusive. These students highlighted that their peers were surprised that they can both be biology majors and be religious. Sometimes this led to the religious students perceiving that their peers think that religious people are not intelligent. For instance, Amy talks about negative encounters she has had with other biology students:

"I've had other students ask me before, 'Well, how can you believe in God if you're a Biology major?' And they'll almost pull this whole intelligence thing like 'How can you be intelligent and an analytical student and believe in God?' So that's probably the most difficult situation. And so people essentially are like, 'Well, how can you believe in God which is stupid and then you know, be a Biology major?' So that for me was the only thing that's been difficult. It's really the students."-Amy, nondenominational Christian

Some students also reported that they felt as though they would not fit in with the biology community as a whole, even beyond the biology class. For instance, Maria talked about how she worried that she might not fit in at academic scientific meetings:

\begin{abstract}
"When I first entered [college], my plan was to stick with academia and become a PhD. So then I imagined myself meeting at conventions with other PhD's and I thought religion is going to come up at some point especially because I wanted to study Animal Behavior and a little bit of evolution, things like that. So, the people are always going to assume, my peers I assume most of them would not be religious because that seems to be the theme, that if you're going to be an evolutionary or some kind of biologist you can't also be religious. So I always imagined at some point that would be a debate."-Maria, nondenominational Christian
\end{abstract}

In addition to feeling as though they might not fit in with the biology community, they also felt as though they might be at a disadvantage because their peers would not like them or would be offended by their beliefs. Maria expressed this fear when she continued to express her perceptions of what it may be like as a religious biologist in academia:

"I know part of living in academia is getting yourself published, getting in with the right people and I can foresee [my religion] having been a problem had I stuck with that because if I offended somebody who I really needed, some professor with a lot of interest, who really I needed his support and if he decided to take offense at the fact that I was religious, that's a conceivable thing for him to take offense at, then that could be hard on my career."-Maria, nondenominational Christian

She and other students expressed a concern that other biologists, particularly elite biologists, would not take their work seriously. Although Maria's quotes best illustrate this theme, four other students expressed similar concerns about feeling they would be negatively stereotyped as religious biologists. Maria continued in her interview to talk about how she was willing to face that challenge, but felt as though her work might be discriminated against because she is religious:

"I think it would be a challenge. It was one I was originally willing to face and I didn't think it would completely hold me back. Maybe I'm optimistic but I thought my science would be good enough and that not everybody's going to discriminate 
but especially with the older crowd and the people who are already well-known in Biology, it could be hard for me to be a biologist and then have people say, 'Well, I'm not going to listen to you. You also believe in God. Why would your science be worth anything? You're obviously not a scientist.' There's always that derogatory attitude that could come from people who are atheists and also biologists."-Maria, nondenominational Christian

In summary, students saw several disadvantages to being a Judeo-Christian student in biology: they perceived that they are in the minority among their peers in class; that peers mocked religion in biology class, which made them uncomfortable; that their peers assumed religion and biology are mutually exclusive; that they would not fit in with the biology community if they pursued biology as a career; and that their biology colleagues might think that their scientific work is not of value.

Biology Instruction in Which Religious Identity Is Relevant. Participants reported a wide variety of experiences in biology classes that were relevant to their religious identities. In line with past research, learning evolution was cited by many participants as the most relevant experience related to their religious identities in biology classrooms (Dagher and BouJaoude, 1997; Griffith and Brem, 2004; Goldston and Kyzer, 2009; Winslow et al., 2011). Participants also reported that instruction that involved bioethics was relevant to their religious identities, particularly when discussing biology content surrounding reproduction. Below, we further outline how participants characterized their experiences of biology instruction as it relates to their religious identities.

Religious Students Saw Instruction on Evolution as Relevant to Their Religious Identities. The overwhelming majority of students we interviewed said that evolution instruction was relevant to their religious identities. When the interviewer asked students what experiences in biology classes were most relevant to their religious identities, students often talked about their experiences learning evolution:

"I think the most direct, to faith and biology, would be the aspect of learning evolution."-Andrew, Protestant

Approximately one-third of students said that they rejected evolution. However, the aspects of evolution these students rejected varied, which is in line with previous research showing that students differentially accept macroevolution (Nadelson and Southerland, 2012) and human evolution (Dagher and BouJaoude, 1997; Nadelson and Southerland, 2012). For instance, Andrew continued on to say he accepted microevolution but doubted macroevolution:

"I mean, obviously, microevolution is impossible to think against. It's very obvious that that's a thing. But macroevolution is definitely a place of controversy. I, for one, would not absolutely believe it as a whole."-Andrew, Protestant

And some students, like Donna, accepted all of evolution except for human evolution:
"Christians do believe evolution, you can see it in sedimentary rocks in the Grand Canyon. You can see that things have evolved. We do not believe in human evolution because we believe that God created Adam and Eve. God did not create Adam and Eve in the form of a primate, $\mathrm{He}$ created them in the form of Him, which is what we look like ... That is the only inconsistency."-Donna, nondenominational Christian

Most students, approximately two-thirds, accepted a view of evolution that is potentially compatible with the scientific view. However, they often also struggled with reconciling evolution and their religious beliefs at one time or another in their lives and they also saw evolution instruction as relevant to their religious identities:

"I'm taking an Evolution course right now and I personally don't see it conflicting with my own faith so much but I know it's always there. It was the first day of our Evolution class actually, the professor spent most of the first lecture talking about the differences between Science and Religion and how he feels that evolution is not the same thing as religious beliefs."-Maria, nondenominational Christian

Religious Students Saw Bioethics as Relevant to Their Religious Identities. Around one-third of our participants mentioned that discussions of topics related to ethics in biology were also particularly relevant to their religious identities. This mirrors the heated public debates in which there is religious-based opposition to biology-related issues such as stem cell research, birth control, and abortion (Charo, 2015; Liptak, 2016; New York Times, 2016). The students we interviewed were most frequently concerned about topics in biology classes related to reproduction and reproductive rights. The topic of abortion in classes was by far the most cited experience related to bioethics that students remembered. They often perceived that they were in the minority in their opinions in class, so they were afraid to contribute to discussions. For instance, Amelia said she was uncomfortable expressing her viewpoint in class:

\footnotetext{
"Sometimes we'd talk about some controversial topics, like I know abortion came up a couple of times ... Sometimes it would make me feel a little uncomfortable if the professor was saying her viewpoint and why pro-life was a bad thing ... we would talk about religion and sometimes she'd ask for volunteers, she'd be like 'does anyone have anything to say about this?' I never felt comfortable enough to be able to speak up."-Amelia, nondenominational Christian
}

Religious Students Had Positive Experiences When Instructors Acknowledged and Respected Their Religious Views and Had Negative Experiences When Instructors Ignored or Belittled Their Views

Positive Experiences. Many students reported that they had previous positive experiences with their instructors that were related to their religious identities. These experiences spanned two categories: instructors who acknowledge religious students or their beliefs and instructors who present evolution and religion as compatible. 
Instructors Who Acknowledge Religious Students and Their Beliefs. Students often cited experiencing a higher level of comfort and belonging in classes in which instructors simply acknowledged religious students in their classes. For instance, Alexis talked about her professor who acknowledged that there were students of different faiths in the room and how it made her far more comfortable in class:

\begin{abstract}
"At the beginning of the semester the professor said 'I know some experiences that you might have probably had being religious in classes and I'm going to teach what science accepts as correct nowadays but I'm going to teach you in a way that is respectful to everyone regardless of faith and things like that [...] It made me feel pretty welcome in the class."-Alexis, nondenominational Christian
\end{abstract}

Many students who were recruited from that same class mentioned a shared positive experience in which their professor acknowledged the religious beliefs of the students before she began her lesson on evolution. The instructor further discussed how several scientists have been able to reconcile evolution with their religious beliefs. All of the following quotes seem to stem from the same experience in a single class:

\begin{abstract}
"She was just talking about how throughout the years there's been a lot of scientists who have backgrounds in faith and have been able to cope with justifying both sides; that they don't have to sacrifice one for the other. She said for us we don't have to worry about having to pick one because there are ways to cope [...] Even though it was one time, it was all I needed, just someone to bring it up and realize that there are religious people in the classroom [It made me feel] Good because I've never really had any science teachers that have brought up the discussion of faith ever. It's kind of like a thing I've had to deal with by myself."-Brittany, Catholic
\end{abstract}

\begin{abstract}
"My current bio professor briefly mentioned during the evolution section that she hopes none of our religious views will deter us from learning the concepts and understanding the facts that we see before us, how they're interpreted and she seems really open to if we want to talk to her about it because we are uncomfortable with some aspect of how she's teaching it [...] I was glad that she addressed it because I think it's a bit of a taboo topic sometimes, science and religion don't really tend to mix, so it was nice that she didn't gloss over it like it's not there."-Carrie, nondenominational Christian
\end{abstract}

Instructors Who Present Evolution and Religion as Compatible. Students usually described experiences in biology classes as positive when instructors highlighted the potential compatibility between religion and evolution. This aligns with past research that showed biology students say they appreciated when instructors discuss the compatibility between religion and evolution (Barnes et al., 2017). For instance, Carrie went on to say later in her interview that she was surprised to hear the professor say that evolution and religion can be compatible, and this made her feel that the instructor cared about her sense of belonging in biology:

"[The professor] did mention in her very short brief speech that a lot of people have found a way to hold both their religious belief and also believe in the science of evolution and that sort of thing ... I don't think I have ever seen them mentioned as coming together at all. It is generally, a lot of the times, you're either creationist or evolutionist ... I think simply by bringing that up she was showing that she does care about our feelings, she doesn't want to see you left out or anything because of that belief, and she does care that we are part of the biology community."-Carrie, nondenominational Christian

Around one-third of our participants reported similar experiences with other biology instructors, in which they felt more comfortable because the instructor in a biology course acknowledged the religious beliefs of students in the classroom or discussed the two as being compatible with one another.

Negative Experiences. In addition to positive experiences, students also reported negative experiences they had in their biology classes that were related to their religious identities. Parallel but opposite to their positive experiences, students had negative experiences when instructors did not acknowledge religion when teaching relevant content and when instructors highlighted conflict between religion and biology. Additionally, students also had negative experiences when they felt as though instructors were authoritarian in their teaching of evolution, when they felt as though instructors had a negative disposition toward religion, and when religious biologist role models were generally unavailable to them in the biology community.

Instructors Who Do Not Acknowledge Religion or Religious Viewpoints. In our interviews, we found evidence that avoiding religion when teaching relevant material can make religious students feel excluded, a finding that parallels that of another study that showed students felt alienated when instructors avoided religion when teaching evolution (Hermann, 2012). Our interviewees said they felt "invisible" or "excluded" when instructors did not acknowledge religious students or their beliefs during relevant instruction. For example, Bethany talked about how she felt as though she is in the minority, when in reality there are probably a lot of religious students in her evolution class:

"It's more just professors not addressing [religion] because especially in biology classes I always feel like I am the only one so it's not worth bringing it up, but in reality there's probably a lot of other students that are religious. So, it just makes the majority feel like the minority."-Brittany, Catholic

Instructors Who Highlight the Conflict between Religion and Biology. Students also said they felt uncomfortable when instructors highlighted only the conflict between religion and biology. Oftentimes, students felt as though biology instructors caricaturized religion and presented it as inferior to science. For instance, Maria described how her evolution instructor compared religion with magic when teaching evolution:

"I think they do [professors] present it [evolution and religion] in a way that is conflictual. I mean in the first lecture of evolution class we went through-he kind of lumped religious faith 
in with magic. He's like, 'They believed in magic and obviously that's wrong. Then they believed in creationism' He's like, 'obviously no one believes in magic, right? They tried making gold and the eternal life, those things didn't work. Then they believed in religion."'-Maria, nondenominational Christian

Instructors Who Try to Force Beliefs on Students. Some students described negative experiences in which they felt as though instructors were trying to force certain beliefs on them. This often occurred in the context of learning evolution. When instructors said things like "You have to accept evolution" or tried to disprove religious ideas, students interpreted this as a negative experience. For instance, Alexis described a negative beginning to her evolution class in which she thought the professor was trying to force her to accept evolution:

\begin{abstract}
"In one of my general biology classes when they were teaching about the theory of evolution they said 'if you don't believe this of course you're wrong because it's proven this is right and you know you have to believe it this way' and then in the evolution class, it's a required class, at the beginning of the class the professor handed everyone sheets of paper and said 'I want everyone to write down reasons that they can prove that evolution is incorrect' and he read them out to everyone and he said 'so this is why these are all really bad reasons and this is why you can't believe anything different and you should believe this.' It kind of made a bad start to the class."-Alexis, nondenominational Christian
\end{abstract}

Instructors Who Have a Negative Disposition toward Religion. The most-cited negative experience among our participants was a general negative disposition toward religion among their biology instructors. This included instructors who were generally dismissive of religious ideas, made jokes at the expense of religion, seemed angry when talking about religion, or seemed condescending to students who brought up religious ideas. For instance, Donna talked about how she became frustrated when an instructor blatantly dismissed the notion of the soul:

\begin{abstract}
"One of my professors said literally, in his mind or what he thinks, is that we are just brainwaves. I remember I asked, I raised my hand, I was like 'How do you explain the soul?' He's like 'Ask your religious leader. That doesn't exist.' ... That one made me mad."-Donna, nondenominational Christian
\end{abstract}

Additionally, James discussed how an instructor seemed to question the intelligence of a religious student, because the student believed there may be a higher power behind the Big Bang:

"A student [in class] brought up some topic about how he's baffled that people can't recognize that the Big Bang might have something else behind it like a higher hand, you know? And the instructor just kind of shut him down. He said 'you're stupid if you believe that.' It was very blatant he was like 'I'm the only one who can say this and this is my class.' [...] it's kind of bizarre to see how some of these professors will preach this openness in the classroom and discussions, but when it comes down to it, when someone brings up something that goes against what they're trying to portray, it's obvious you know they're truly not."-James, Lutheran
Maria discussed how she felt as though biology instructors, particularly evolution instructors, seem angry when they talk about religion in relation to biology, and this made her feel as though there is tension between religion and biology:

\begin{abstract}
"I see this with a lot of professors when they start talking about evolution, people who are high up and studying evolution or genetics, they get angry when they talk about it [religion]. They're like 'Today we're going to explain why this is capital, bold point [sic] letters, RELIGION AND NOT SCIENCE.' Then in that whole lecture, there's like an angry attitude to it. So you can always feel it, even if you didn't know at that point that there's tension between evolutionary biologists and religious people."-Maria, nondenominational Christian
\end{abstract}

Not Having Religious Scientist Role Models. Many students commented on the lack of religious individuals in the community of biology. Students expressed that it was disheartening that there were so few religious scientist role models available to them in the biology community:

"I feel like every teacher that I've ever had in any science class has not been a person of faith and it's hard to look at someone as your role model in science but not as your role model in your own faith."-Brittany, Catholic

In summary, we found that instruction in evolution and bioethics topics were most relevant to our participants' religious identities. Further, we found that these students felt more comfortable in class when they were acknowledged and respected, but felt less comfortable in class when instructors belittled, made jokes, or became angry about religion. Additionally, we found that students felt a lower sense of belonging when they did not perceive that there are biologists who are religious.

\section{DISCUSSION}

Our study is the first to our knowledge to characterize the positive and negative experiences of religious students in biology that affect their comfort in biology classes. We found that our participants were often able to reconcile their religious identities with biology, but most of them experienced struggles along the way. Students reported that sometimes they feel as though they have the minority opinion in their classes and subsequently feel uncomfortable sharing their thoughts and ideas about relevant topics. They also sometimes feel as though instructors can be insensitive or aloof when teaching subjects that are relevant to students' religious identities. Further, some students perceive that being religious in biology can be a disadvantage, because colleagues may not value their scientific work and they may not fit in with the biology community. Finally, we found that biology instruction in specific content areas such as evolution and ethics may present challenging situations for religious students and that instructional practices can impact how religious students feel. However, students also reported experiences that can increase their sense of belonging in biology. For instance, students said they felt more included when instructors acknowledged the beliefs of religious students when teaching evolution, and they felt more like they belonged in biology when they saw religious biology instructors as role models. In the following sections, we outline the implications of our research for biology 
instruction, the limitations of the current study, and recommendations for future areas of research.

\section{Teaching Evolution}

Our data reveal that instructors interested in helping religious students gain a sense of belonging in biology classes could consider how inclusive their instructional practices are when teaching evolution. Almost all of our participants cited learning evolution as an experience that was relevant to their religious identities, and often these experiences were negative, even when the religious students personally had positive attitudes toward evolution. Instructor humor about religion and caricaturizing religion as something akin to believing in magic or belief for which there is no evidence was overwhelmingly seen as alienating by our participants. Although instructors may find that humor about religion can amuse the secular portion of a class, we encourage instructors to think about the potential message that unnecessarily negative remarks and humor about religion might send to religious students in their classes.

Beyond a general condescension toward religion being problematic, our interviews indicate that Judeo-Christian student perceptions of evolution instruction are complicated and may depend on individual student beliefs. If instructors only discuss the conflict between evolution and religion, a religious student who thinks evolution and religion are compatible may feel as though his or her beliefs have been characterized by the instructor incorrectly. However, if an instructor discusses only how evolution and religion are compatible, this may present challenges for a student who thinks evolution and religion are in conflict and he/she may feel as though this instructor is advocating for a particular religious interpretation with which the student does not agree. Further, some students do not know that it is possible to reconcile some religious beliefs with evolution, so if instructors do not discuss this, students may self-propagate their own conception that their beliefs and evolution must be in conflict. This leads us to believe that acknowledging that there are a diversity of perceptions about the relationship between evolution and religion could be helpful for increasing Judeo-Christian students' sense of belonging in biology.

Discussing Various Viewpoints on Religion and Evolution. Our interviews add to a growing literature that indicates religious students will likely benefit if evolution instructors discuss varying viewpoints on religion and evolution (Dagher and BouJaoude, 1997; Roth, 1997; Brickhouse et al., 2000; Manwaring et al., 2015; Barnes et al., 2017). Acknowledging different viewpoints can serve several instructional purposes.

First, educating students on the various viewpoints on evolution and religion may expand student perspectives on what is possible for them to simultaneously believe and ultimately increase their sense of belonging in biology. In fact, past research from our group shows that discussing multiple perspectives can reduce perceived conflict between religion and evolution among students (Barnes et al., 2017). Among our participants in this study, students who accepted evolution and saw no conflict between religion and evolution tended to say they were more comfortable when learning evolution and felt more like they belonged in evolution classes. If students are informed of the potential compatibility between religion and evolution, this may help them feel more comfortable in biology classes.
Also, a discussion of the various viewpoints on evolution can provide instructors with a potential opportunity to educate students on the nature of science (Smith, 1994; Southerland and Scharmann, 2013). Instructors can briefly outline varying viewpoints on the relationship between religion and evolution and place these views on a continuum from most consistent to least consistent with what is known from scientific exploration (for a review of common positions held by students and the scientific consistency of these views, see Yasri and Mancy, 2016). When instructors compare perspectives such as theistic evolution, agnostic evolution, and atheistic evolution, this can establish a framework for discussing what is science and what is not science. Therefore, students have an opportunity to reflect on their own positions given their religious beliefs and also to understand more about the nature of scientific inquiry and what is the domain of science. Further, by discussing various viewpoints, instructors can create what some researchers have termed "brave spaces," where students are provided with an environment in which they feel comfortable exploring different viewpoints and confronting potential conflicts (Arao and Clemens, 2013; Cook-Sather, 2016).

As we saw with our participants, some religious biology students may hold views that are in stark contrast to the accepted scientific view, such as special creationists who believe that humans were created by God in their current form, and this can pose a unique challenge for instructors who do not want to make their students uncomfortable when teaching evolution. However, discussing various viewpoints can serve a purpose for students with incompatible conceptions as well, if it is delivered in a manner that is sensitive to the students' beliefs. An instructor can acknowledge that some students in a class may hold special creationist beliefs, acknowledge that those beliefs are not consistent with what biologists currently accept, but also acknowledge that the instructor is going to respect all viewpoints in the class and welcome questions. It is important to make clear that we do not recommend that instructors give credibility to these viewpoints that are clearly in opposition to what we know from empirical observations and experimentation in biology. However, by making the student feel respected and heard, past research shows this will not only make the student feel more comfortable in class but also may encourage him or her to have a more positive attitude toward evolution (Dagher and BouJaoude, 1997; Hermann, 2012). The National Academy of Sciences (2008) book Science, Evolution, and Creationism can serve as a beginning resource for instructors who would like to incorporate this inclusive type of instruction when teaching evolution.

Religious Scientist Role Models. One way to discuss varying viewpoints on religion and evolution is to present scientists who hold different views about religion and evolution. A frequently occurring theme from our interviews was that students perceived there are few role models in biology who hold their same religious beliefs. Our study adds to the growing body of research showing that religious scientist role models are potentially important for religious students in biology (Winslow et al., 2011; Barnes et al., 2017). Showing students examples of individuals who have been successful in biology and also hold religious beliefs could provide these role models that students seek, while also acknowledging the diversity of religious viewpoints within biology. For instance, Francis Collins, the current director of the 
National Institutes of Health and former director of the Human Genome Project, has written a book called The Language of God and has founded the organization BioLogos to promote harmony between Evangelical Christianity and evolution (Collins, 2006). Additionally, Ken Miller is a biologist who served as a witness in the Dover Pennsylvania Evolution Trial to defend the teaching of evolution and exclusion of creationism in the biology curriculum. $\mathrm{He}$ is also a Catholic and authored the book Finding Darwin's God: A Scientist's Search for Common Ground between God and Evolution. Presenting these individuals to students as role models may help the students feel more comfortable with holding a religious identity and accepting evolution (Miller, 2002).

Additionally, presenting religious scientist role models can be a particularly important strategy for instructors who may not relate to their students' struggles with evolution and religion. In a past study, we found that the majority of public college biology instructors we interviewed reported that they had not experienced a worldview conflict with evolution and religion, which we attributed to lower levels of religiosity among instructors in our study (Barnes and Brownell, 2016). Indeed, the majority of instructors in our study took a purely atheistic view of evolution. Secular instructors may struggle with religious student viewpoints on evolution and with acting as role models for these religious students. However, these instructors can still provide support to religious students by referencing other scientists who have managed to reconcile their religious beliefs with evolution.

Importance of Evolution for Students Pursuing Medicine. Another potentially important finding from our interviews is that students who see a conflict with their religious beliefs and evolution may choose careers in the medical field, in part because they do not see evolution as relevant to a career in medicine. This is concerning, in that we may be inadvertently selecting for nonreligious students in research careers. If we do not address the potential compatibility of religion and evolution with our students who might otherwise be interested in research careers if they did not see a conflict with religion and evolution, then this could lead to a disproportionate number of JudeoChristian students in the medical sciences and a disproportionate number of non-Judeo-Christian students in research careers. However aside from concerns of exclusion from research careers, it is additionally concerning that Judeo-Christian students hold the notion that evolution is irrelevant for a medical career. Several researchers in evolutionary biology and medicine have indicated the importance of understanding the role of evolution in human disease, including some of the most prevalent ailments in human society today such as obesity, heart disease, and mental illness (Lieberman, 2013; Nesse, 1996). The importance of understanding evolution for practicing and researching medicine has become so apparent that some have suggested evolutionary medicine should be taught to all medical students (Nesse et al., 2010).

\section{Ethics-Relevant Content}

Our interviews also revealed that instructors interested in helping religious students feel comfortable in biology classes may want to pay particular attention to their instructional practices when teaching topics related to ethics in biology, such as stem cell research, abortion, and birth control. Given that many top- ics at the intersection of religion and bioethics have been a modern source of public and political debate (Charo, 2015; Liptak, 2016; New York Times, 2016), it is unsurprising that students see this content as relevant to their religious identities. However, similar to the teaching of evolution, this means instructors may have to take extra care to create an inclusive environment for religious students when teaching bioethicsrelated topics (Smith, 1994; Southerland and Scharmann, 2013). As in teaching of evolution, acknowledging and respecting diverse viewpoints may make students feel more comfortable (Smith, 1994; Southerland and Scharmann, 2013; Barnes et al., 2017). Teaching content at the intersection of religion and bioethics could be an opportunity for instructors to encourage a discussion that includes diverse opinions. Instructors can model equity in science to their students by valuing diverse opinions and showing how this diversity can lead to new and interesting ways of understanding the ethical debates surrounding biology topics. Similar to other groups with cultural norms and values that differ from the scientific community (Brown et al., 2016), if religious students feel as though their values are respected and represented in the biology community, this could lead to their greater sense of belonging in biology.

\section{Intersection of Biology Identity, Religious Identity, and Belonging}

Our interviews, along with past interview studies, indicate that there may be a complex reciprocal relationship between a student's religious identity and the development of a student's biology identity over a degree (Winslow et al., 2011). Ideally, biology students will develop strong biology identities over their years of study (Trujillo and Tanner, 2014). However, our interviews suggest that students' religious identities can hinder the development of their biology identities. For instance, the students we interviewed said they restricted their biology identities to realms of biology in which they did not see a conflict with their religious identities, and this limited the types of biology-related careers they could pursue. Students who rejected evolution due to their religious beliefs did not see research, particularly in ecology and evolutionary biology, as viable career options. In addition, students who rejected evolution restricted their biology identities to certain classes and subjects that did not conflict with their religious identities. When students took classes that covered topics that conflicted with their religious identities, they said they were less excited about the material and learned it just for the grade but did not meaningfully engage with the material. Further, a student's religious identity may also be shaped by an emerging biology identity (Winslow et al., 2011). Many of our students discussed how they actually changed their religious beliefs in response to their experiences in biology classes. This indicates that biology classes inform both students' religious identities and their biology identities.

However, we did not ask students specifically about their biology identities in our interviews, so we feel as though our findings can only be interpreted as a preliminary indication of an interplay of religious and science identities. While we had many indirect references in our interviews that indicated biology identities among our students, we were not able to gauge the salience of those identities from the interviews. Future research should probe the saliency of students' religious and biology identities to see how these two identities influence one 
another over the course of the biology major and how experiences in biology classes can affect both of these identities.

Our interviews also indicate that religious identity could impact students' sense of belonging in class, which in turn can impact their biology identities. This study is a preliminary step toward illustrating ways in which religious identity might impact belonging. While there are survey instruments that could be used to measure sense of belonging (Trujillo and Tanner, 2014), we did not feel that a survey measure would be meaningful in the context of our study, due to the small sample size and lack of a comparison group that would allow us to generalize the scores from a survey. Further, we found indication of a potential social desirability bias for students to report a higher sense of belonging that might influence survey responses. As reported previously, when we asked students if they felt as though they belonged in their biology classes, the majority of students said that they did feel as though they belonged. However, their responses to other questions indicated that at times they did not feel as though they belonged. When we asked students about specific experiences, such as times that instructors made them feel like they did not value religious beliefs or what disadvantages there are to being religious in biology, we received a wealth of responses that indicated experiences that would negatively impact sense of belonging. This indicates that, although students may report that they feel like they belong, they may have experiences that indicate a lower sense of belonging than other students who do not have those experiences.

\section{Limitations}

This study was conducted with students in a research-intensive public institution in the Southwest. The results of this study could be unique to this demographic and geographic population. However, perceived conflict between religion and evolution has been documented among a wide range of student populations and demographics (Dagher and BouJaoude, 1997; Brem et al., 2003; Martin-Hansen, 2006; Donnelly et al., 2008; Winslow et al., 2011; Hermann, 2012; Yasri and Mancy, 2016; Barnes et al., 2017), so we suspect that religious students from a diverse array of institutions and geographic regions will grapple with some conflict in some biology classes. It will be important to extend these findings by exploring experiences of students at a wide range of institutions in different geographic regions in order to triangulate how institutional and regional factors may produce differential experiences among religious students in biology.

We have a sampling bias in our study by the nature of its design. We handed out fliers to every student attending our targeted classes, but it is impossible to know the characteristics and experiences of religious students who chose not participate in our study. We acknowledge that it could be possible that the pool of interviewees who were willing to talk are not necessarily reflective of the larger population of religious students, so our findings should be interpreted cautiously. However, it is possible that students who perceive a great amount of conflict between their religious identities and biology may have chosen not to participate, because they may feel uncomfortable discussing such personal matters in an interview. Alternatively, it is also possible that students who perceived a great deal of conflict may have disproportionately responded to the fliers, because the subject is important to them. We attempted to address this limitation by gathering a diversity of responses to assess the landscape of experiences (Glesne and Peshkin, 1992) and by avoiding any quantitative generalizations based on the data.

These were self-reports of students' experiences and not observational data. Factors that influence the way individual's self-report, such as social desirability bias, could have influenced these results (Edwards, 1957), and some of the students' experiences and perceptions may not be accurately represented. Students may have had experiences that they could not remember that may have impacted their sense of belonging in biology or they may have inaccurately recalled the experiences they could remember. However, this is a limitation of most interview studies, which are often seen as a first step in exploring a new research area in order to subsequently inform more systematic and observational research (Glesne and Peshkin, 1992).

Further, we did not explore the experiences of students from non-Judeo-Christian religious backgrounds. We did not intend to limit our sample, but merely were unable to recruit students from other religious belief systems. Future research should begin to explore differences among students from different religious traditions. Similar to how the term "underrepresented minority" refers to multiple groups of people with unique social identities and experiences, by referring to "religious students" we are not taking into account the differences among those students' beliefs. It will be important for future researchers to explore these populations and their experiences, to ascertain what may make them feel more included and supported in the biology community.

Finally, our study does not assess the causal impact of these students' experiences on their sense of belonging or their persistence in biology. Interview studies are seen as exploratory in novel areas of research, so our study was meant to illuminate potentially interesting areas of inquiry within religious students' experiences. In addition to exploring a greater number of students from different populations, future research should also establish whether and how these experiences impact students' sense of belonging and their retention as biology majors.

\section{CONCLUSION}

Our interview study serves as a source of information for college biology teachers and is meant to illuminate the experiences that could contribute to how religious students feel they are perceived in biology classes. We hope that our findings will stimulate a discussion within the higher education biology community on the importance of making college biology equitable for all students, including those with religious beliefs. We hope by making biology more accessible to religious individuals we can progress further in our mission to meet the STEM workforce needs of the 21st century.

\section{ACKNOWLEDGMENTS}

We acknowledge a National Science Foundation fellowship (DGE-1311230) for graduate student support during this project. We thank Katey Cooper and the rest of the Biology Education Research lab at Arizona State University for their helpful comments and feedback. 


\section{REFERENCES}

American Association for the Advancement of Science (2011). Vision and Change in Undergraduate Biology Education: A Call to Action, Washington, DC.

Arao B, Clemens K (2013). From safe spaces to brave spaces. In: The Art of Effective Facilitation: Reflections from Social Justice Educators, Sterling, VA: Stylus, 135-150

Barnes ME, Brownell SE (2016). Practices and perspectives of college instructors on addressing religious beliefs when teaching evolution. CBE Life Sci Educ 15, ar18.

Barnes ME, Elser J, Brownell SE (2017). Two-week evolution module reduces perceived conflict between evolution and religion for religious and non-religious students. Am Biol Teach 79(2), 104-111.

Brem SK, Ranney M, Schindel J (2003). Perceived consequences of evolution: college students perceive negative personal and social impact in evolutionary theory. Sci Educ 87, 181-206.

Brickhouse NW, Dagher ZR, Letts IV WJ, Shipman HL (2000). Diversity of students' views about evidence, theory, and the interface between science and religion in an astronomy course. J Res Sci Teach 37, 340-362.

Brown BA, Henderson JB, Gray S, Donovan B, Sullivan S, Patterson A Waggstaff W (2016). From description to explanation: an empirical exploration of the African-American pipeline problem in STEM. J Res Sci Teach 53, 146-177.

Brownell SE, Freeman S, Wenderoth MP, Crowe AJ (2014). BioCore Guide: a tool for interpreting the core concepts of vision and change for biology majors. CBE Life Sci Educ 13, 200-211.

Charo RA (2015). Scientists curbing the use of science. New York Times. www nytimes.com/roomfordebate/2015/05/28/scientists-curbing-the -ethical-use-of-science/the-case-of-embryonic-stem-cell-research (accessed 11 April 2016)

Collins FS (2006). The Language of God: A Scientist Presents Evidence for Belief, New York: Simon and Schuster.

Cook-Sather A (2016). Creating brave spaces within and through student-faculty pedagogical partnerships. Teach Learn Together High Educ $1(18), 1$.

Coyne JA (2015). Faith versus Fact: Why Science and Religion Are Incompatible, New York: Penguin

Dagher ZR, BouJaoude S (1997). Scientific views and religious beliefs of college students: the case of biological evolution. J Res Sci Teach 34, 429-445.

Dawkins R (2009). The God Delusion, New York: Random House.

Donnelly LA, Kazempour M, Amirshokoohi A (2008). High school students perceptions of evolution instruction: acceptance and evolution learning experiences. Res Sci Educ 39, 643-660.

Ecklund EH, Scheitle CP (2007). Religion among academic scientists: distinctions, disciplines, and demographics. Soc Probl 54, 289-307.

Edwards AL (1957). The Social Desirability Variable in Personality Assessment and Research, Ft Worth, TX: Dryden.

Espinosa $L$ (2011). Pipelines and pathways: women of color in undergraduate STEM majors and the college experiences that contribute to persistence. Harvard Educ Rev 81, 209-241.

Freeman TM, Anderman LH, Jensen JM (2007). Sense of belonging in college freshmen at the classroom and campus levels. J Exp Educ 75, 203-220.

Glaser BG, Strauss AL (1967). The Discovery of Grounded Theory: Strategies for Qualitative Research, Chicago: Aldine.

Glesne C, Peshkin A (1992). Becoming Qualitative Researchers: An Introduction White Plains, NY: Longman.

Goldston MJ“D”, Kyzer P (2009). Teaching evolution: narratives with a view from three southern biology teachers in the USA. J Res Sci Teach 46 , 762-790.

Good C, Rattan A, Dweck CS (2012). Why do women opt out? Sense of belonging and women's representation in mathematics. J Person Social Psychol 102, 700

Griffith JA, Brem SK (2004). Teaching evolutionary biology: pressures, stress, and coping. J Res Sci Teach 41, 791-809.

Hallgren KA (2012). Computing inter-rater reliability for observational data: an overview and tutorial. Tutor Quant Methods Psychol 8, 23-34.

Ham K (2010). The New Answers Book, Green Forest, AR: Master Books.
Harris S (2005). The End of Faith: Religion, Terror, and the Future of Reason, New York: Norton.

Hermann RS (2012). Cognitive apartheid: on the manner in which high school students understand evolution without believing in evolution Evol Educ Outreach 5, 619-628.

Intemann K (2009). Why diversity matters: understanding and applying the diversity component of the National Science Foundation's broader impacts criterion. Soc Epistemol 23, 249-266. http://doi.org/10.1080/ 02691720903364134

Krippendorff K (2012). Content Analysis: An Introduction to Its Methodology Thousand Oaks, CA: Sage.

Landis JR, Koch GG (1977). The measurement of observer agreement for categorical data. Biometrics 33, 159-174.

Lieberman D (2013). The Story of the Human Body: Evolution, Health, and Disease, Vintage.

Liptak A (2016). Supreme Court appears sharply divided as it hears Texas abortion case. New York Times. www.nytimes.com/2016/03/03/us/politics/ supreme-court-abortion-texas.html?_r=0 (accessed 11 April 2016).

Manwaring KF, Jensen JL, Gill RA, Bybee SM (2015). Influencing highly religious undergraduate perceptions of evolution: Mormons as a case study. Evol Educ Outreach 8, 23.

Martin-Hansen LM (2006). First-year college students' conflict with religion and science. Sci Educ 17, 317-357.

Miller JD, Scott EC, Okamoto S (2006). Public acceptance of evolution Science 313, 765-766

Miller KR (2002). Finding Darwin's God: A Scientist's Search for Common Ground between God and Evolution, New York: HarperCollins.

Murphy MC, Steele CM, Gross JJ (2007). Signaling threat: how situational cues affect women in math, science, and engineering settings. Psychol Sci 18, 879-885

Nadelson LS, Southerland S (2012). A more fine-grained measure of students' acceptance of evolution: development of the Inventory of Student Evolution Acceptance-I-SEA. Int J Sci Educ 34, 1637-1666.

National Academy of Sciences (2008). Science, Evolution, and Creationism, Washington, DC: National Academies Press

Nesse RM (1996). Why We Get Sick: The New Science of Darwinian Medicine Vintage Books.

Nesse RM, Bergstrom CT., Ellison PT, Flier JS, Gluckman P, Govindaraju DR Niethammer D, Omenn GS, Perlman RL, Schwartz MD, et al. (2010). Making evolutionary biology a basic science for medicine. Proc Natl Acad Sci 107(suppl 1), 1800-1807.

New York Times (2016). Religion and birth control at the Supreme Court, New York Times. www.nytimes.com/2016/03/21/opinion/religion-and-birth -control-at-the-supreme-court.html?_r=0 (accessed 11 April 2016)

Numbers RL (2006). The Creationists: From Scientific Creationism to Intelligent Design, Cambridge, MA: Harvard University Press.

Pew Research Center (2009). Scientists and Belief. www.pewforum.org/ 2009/11/05/scientists-and-belief (accessed 15 April 2016)

President's Council of Advisors on Science and Technology (2010). Prepare and Inspire: K-12 Education in Science, Technology, Engineering, and Math (STEM) for America's Future, Executive Report, Washington, DC.

Rios K, Cheng ZH, Totton RR, Shariff AF (2015). Negative stereotypes cause Christians to underperform in and disidentify with science. Social Psychol Person Sci, 1948550615598378

Roth W (1997). The interaction of students' scientific and religious discourses: two case studies. Int J Sci Educ 19, 125-146.

Satlin A (2012). Paul Broun: evolution, big bang "lies straight from the pit of hell." www.huffingtonpost.com/2012/10/06/paul-broun-evolution-big -bang_n_1944808.html (accessed 6 November 2015).

Scott EC (2005). Evolution vs. Creationism: An Introduction, Los Angeles: University of California Press.

Smith MU (1994). Counterpoint: belief, understanding, and the teaching of evolution. J Res Sci Teach 31, 591-597.

Southerland SA, Scharmann LC (2013). Acknowledging the religious beliefs students bring into the science classroom: using the bounded nature of science. Theory Pract 52, 59-65. 
Steele CM, Aronson J (1995). Stereotype threat and the intellectual test performance of African Americans. J Person Social Psychol 69, 797.

Steele CM, Spencer SJ, Aronson J (2002). Contending with group image: the psychology of stereotype and social identity threat. Adv Exp Soc Psychol 34, 379-440.

Strayhorn TL (2011). Sense of belonging and African-American student success in STEM: comparative insights between men and women. In: Beyond Stock Stories and Folktales: African Americans' Paths to STEM Fields, vol. 11, ed. HT Frierson and WF Tate, Emerald Group, $213-$ 226.

Strayhorn TL (2012). College Students' Sense of Belonging: A Key to Educational Success for All Students, New York: Routledge.

Sue DW, Bucceri J, Lin Al, Nadal KL, Torino GC (2009). Racial microaggressions and the Asian American experience. Asian American J Psychol S, 88-101.
Sue DW, Capodilupo CM, Torino GC, Bucceri JM, Holder AM, Nadal KL, Esquilin $M$ (2007). Racial microaggressions in everyday life: implications for clinical practice. Am Psychol 62, 271-286.

Tinto V (1993). Leaving College: Rethinking the Causes and Cures of Student Attrition, 2nd ed., Chicago: University of Chicago Press.

Trujillo G, Tanner KD (2014). Considering the role of affect in learning: monitoring students' self-efficacy, sense of belonging, and science identity CBE Life Sci Educ 13, 6-15.

Winslow MW, Staver JR, Scharmann LC (2011). Evolution and personal religious belief: Christian university biology-related majors' search for reconciliation. J Res Sci Teach 48, 1026-1049.

Yasri P, Mancy R (2016). Student positions on the relationship between evolution and creation: what kinds of changes occur and for what reasons? J Res Sci Teach 53, 384-399. 